\title{
パーソナル・コンピュータね用いた工程管理 \\ システムの開発に関する方法論的研究

\author{
METHODOLOGICAL STUDY ON PERSONAL COMPUTER-BASED \\ MANAGEMENT SYSTEM DEVELOPMENT FOR \\ CONSTRUCTION PLANNING AND SCHEDULING
}

\author{
池田將明*.吉川和広**.春名 攻*** \\ By Masaaki IKEDA, Kazuyoshi YOSHIKAWA \\ and Mamoru HARUNA
}

\begin{abstract}
It is well known that network technique e.g. PERT/CPM has not been diffused in construction site-offices for planning and scheduling. We thought there were two main reasons which were a insufficiency of network method and some difficulty to use computer in site-office. Then in order to improve such drawbacks, we have been tried to renew PERT/CPM, and we have developed a personal computerbased management system called PF-NETS, Planning Forecasting-NETwork System. In this paper, we epitomize our recent results of study. And the purposes of this research project are : (a) to demonstrate the viability of applying this system, (b) to find out some problems, and (c) to show the way to explore them by A.I. techniques. In this process we discovered the new concept which indicate a discrepancy between hierarchical networks. And we named the higher level network "Conceptional Network".

Keyrwords : construction management system, preceedence network, PERT, conceptional network
\end{abstract}

\section{1.はじめに}

わが国の建設業界に，䪊的な工程管理手法として PERT (Program Evaluation and Review Technique) が導入されてから，すでに 20 年余りが経った。 これ は，建設業における大型コンピュータの導入と時を同じ くしており，建設業におけるコンピュータ活用というこ とからも, 当時 PERT の積極的な導入が試みられた.

しかし，この間になされた多くの先人達の努力にもかか わらず,一部の大型プロジェクトを除き, 現状において PERT がそれほど活用されているとはいいがたい 状況 にある.この原因にはいくつか考えられるが，工事現場 事務所 (以後, 作業所とよぶ) におけるコンピュータ利 用の困難さも，大きな支障要因の 1 つであったと考え る.

しかし，近年になってパーソナル・コンピュータ（以 後, パソコンとよぶ）が急速に作業所へ導入されるよう になったことから，この要因に対する環境もかなり変わ ってきている. また，これに呼応して多くの企業で工程

\footnotetext{
* 正会員 フジタ工業 (株) 土木本部工事統括部 (テ151 渋谷区干䭾ケ谷 4-6-15)

** 正会員 工博 京都大学教授 工学部土木工学科 (T603 京都市左京区吉田本町)

*** 正会員 工博 京都大学助教授 工学部土木工学科 (同上)
}

管理業務 [以後, 特に断わらない限り計画 (Planning)・ 指揮 (Directing) ・統制 (Controling) のマネジメント 業務のことを“管理 (management)”とよぶ]につい てもシステム化が試みられるようになってきた. また, 現在，パソコンを用いて個別に開発が進められている原 価, 資材, 労務などの各業務システムも, 運用が進むに 従って，工程管理システムを中心としたトータル工事管 理システム (On-site Management System) に統合化し ていこうという, 次段階の合理化をにらんだ試みむなさ れるようになってきだ.

以上の状況から，われわれは PERT 系ネットワーク 手法を用いた工程管理業務のシステム化が重要な課題で あると判断した. そして，トータル工事管理システムの 中核となるようにネットワーク手法を改良し，これを適 用した実験システムを開発し，実際の建設工事に適用す ることにより，その有效性を実証することを考えた.

本論文は，このようなねらいのもとで，2. では現状 における PERT を中心としたネットワーク手法適用の 問題点を整理した. 3. ではシステム開発に適用する目的 で行ったネットワークモデルの改良を紹介する，また， 4. ではパソコン用:開発した工程管理支援 システム PF-NETS (Planning Forecasting-NETwork System) の概要について述べる.また 5. では, 本システムを下 
水管敷設工事に適用した 概要を紹介し，最後の 6.で は，適用結果の分析から発見した“階層間のずれ”とい う現象と，これに伴う“概念ネットワーク”の定義, さ らにはこの問題に対する知識工学手法適用の考え方を示 した.

\section{2. 建設工事における PERT 適用の問題点}

建設工事に PERT を適用する場合の問題点は, これ までいろいろな場で議論されてきている ${ }^{2)}$ が，以後の議 論の参考とするために，これら問題点の整理を試みた.

ここでは，これらの問題点を，PERT を建設工事へ適 用する場合の問題点と，これを利用する場合の使用上の 問題に分けて整理した.

\section{（1）建設工事適用上の問題点}

a）工程表現の自由度に関する問題

PERT における “先行作業 $\rightarrow$ 後続作業” という順序関 係は，非常に簡潔で理解しやすいというメリットをもつ 反面，並行作業等，建設工事でよくある作業間の関係を うまく表現することが難しいという欠点もある.このた め, これまでにプレシーデンス・ネットワーク法 (Precedence Network, 以後 PN 法とよぶ) 等の PERT を 改良した手法が開発されてきた. しかし，これでもなお 建設工事での適用には制約があると考えられるので，後 に述べるように，作業パターン分析による手法の改良を 検討する必要がある.

b）計画案の実行可能性に関する問題

よく知られているように，PERT はプロジェクトの 全体工期を知ることを目的に開発され，後に投入資源や コストに関するデータも加え，工程の最適化を図る手法 に拡張されてきた. しかし，資源やコストまでを考慮し て数学的に最適解を求めることは; 解の組合せが膨大な 数となることから事実上不可能と考えられ，実際にはい くつかの簡便法 (山崩し法) が提案されているにすぎな い.このため, 作成された工程計画の実行可能性には疑 問が残る. この点は, 今後の検討課題である ${ }^{32}$.

c）計画方式の相違による問題

PERT は未知なる プロジェクトを対象に開発された 手法であるため, 詳細部分から全体計画を組み立てる方 法を基本としている. しかし，建設工事では一般的にト ップダウン的に計画化される場合が多いので，これに適 用するためには，手法になんらかの仕組みを考える必要 がある.この方法の 1 つとして, ネットワークの階層構 造化がある，つまり，階層性を利用することにより，不 確実性の減少を伴う工事の進行に従って，上位レベルの ネットワークをサブネットに詳細化していくことが合理 的に行えると考える. なお，以上のような計画方式の違 いは，積上方式と 割付方式といら言葉で表わされてい
る).

d）工事のタイプとの適合性

建設工事にはいくつかのタイプが存在し，たとえばシ ールドの掘進計画やダムのコンクリート打設計画のよう に，ネットワークで記述するより他の手法を用いた方が 妥当と考えられる工事が存在する。しかし，今後開発が 進むと予測されるトータル工事管理システムの中核に, 工程管理システムが位置することを考えると, 現在不適 当と考えられる工事へもネットワーク手法を適用できる ように，手法の改良を図る必要がある。

\section{（2） PERT 使用上の問題点}

a) コンピュータ利用の煩雑さ

PERT を実際の業務に適用する場合は, アクティビ ティーが多くなり，コンピュータの利用が不可欠であ る. しかしここれまでは本支店の大型コンピュータが用 いられてきたため, 作業所での利用にはかなり手間のか かる状況であった. しかし, 本論文で紹介するパソコン 利用システムや，オンライン・ネットワークによる大型 コンピュータ利用等により, この問題点は, 今後急速に 解消されることと予想される.

b) データ作成の煩雑さ

PERT を利用する場合には，一般に詳細なデータを 必要とするため， データ作成作業が大きなネックとな る.しかし，これらのデータの中には，コンクリート構

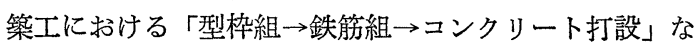
ど一連の順序関係や，階層的な作業分割など, 経験的知 識から容易に推定できるデータが多く含まれている，そ こで，これらの経験的知識を蓄積する知識ベースや，そ れらを計画に自動的に取り込む $\mathrm{AI}$ 技術の適用が，この 問題の主な解決策となるのではないかと考える.

c）計画変更への対応の難しさ

建設工事では，その特性である不確実性の多さから， 計画時に扔ける代替案作成のための条件変更や, 着工後 に括ける計画変更が，頻繁に行われる，現在，PERT を中心とするネットワーク手法の利用頻度の低い最大の 理由は，これらの変更が多大の手閒を必要とすることに あるものと考えられる，そこで，作業内容や順序関倸の 修正を容易とするようなマンマシン・インターフェイス の開発が必要となる. 本論文では, この点に関して, 後 に述べるようにプロジェクト・グラフによる方法を提案 している.

\section{3. エ程ネットワーク・モデルの改良}

ここでは, 工程管理業務にネットワーク手法を適用す る場合の問題点の一部を解消し，システム化する目的で 行った, ネットワーク手法の改良について述べる.

（1）ネットワーク表現方法の改良 
PERT では工程が表現しにくいという問題が 指摘さ れているが, この改善方法として，表一1 に示した $4 つ$ の作業間順序関係とタイムラグ（time lag）を表現でき るネットワーク・モデルを考案し，PF-NETS に適用 した.これは, PN 法から FS (Finish to Start) 関係 と SS (Start to Start) 関係を取り入れ，これに加えて， 後続作業が 先行作業の作業時刻を規定する BF (finish BeFor start) 関係と，労務，機械，資材などの資源転 用を表わす RE (REsource removement) 関係といら 作業間の順序関係を新たに取り入れたものである。そこ で，このモデルを改良プレシーデンス・ネットワーク法 （改良 PN 法）とよぶこととした.

この結果，PN 法によるもの（前半4つ）を加えて, 以下のような $6 つ の$ 特徴をもつようになった. また，こ のネットワーク・モデルの適用例とその計算結果を 図一 1 と表一2 亿示す5). この例では, コンクリート・ポンプ

\section{表一1＼cjkstart改良プレシーデンス・ネットワーク法の 作業順序関係}

\begin{tabular}{|c|c|c|}
\hline 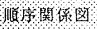 & 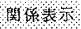 & 内 $\quad$ r \\
\hline $\mathrm{A} \rightarrow \mathrm{B}$ & $\mathrm{FS}=\mathrm{n}$ & $\begin{array}{l}\text { 先行作業Aの終了後、n日以後に後続作業B加開始 } \\
\text { できる。。 }\end{array}$ \\
\hline $\mathrm{A} B$ & $S S=n$ & 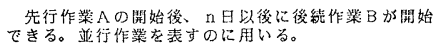 \\
\hline $\mathrm{A}<\mathrm{B}$ & $B F=n$ & 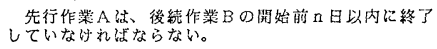 \\
\hline $\mathrm{A}-\mathrm{B}$ & $R E=n$ & $\begin{array}{l}\text { 計算上はFS関係と同しだが、工事用资源の転用関係 } \\
\text { を集すの用いる。 }\end{array}$ \\
\hline
\end{tabular}

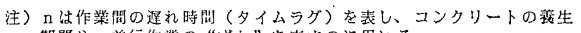

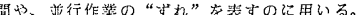

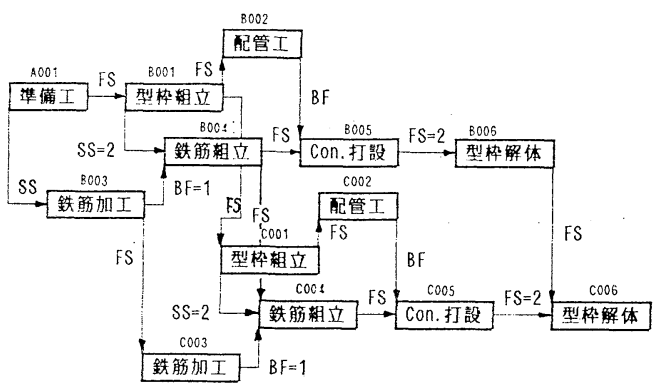

图一1 改良プレシーデンス・ネットワーク法の適用例
打設とそのための配管作業，それに鉄筋組立作業とその ための加工作業の間の関係を $\mathrm{BF}$ 関係で表現している.

(1) SS 関係により，並行作業関係の表現が容易であ る

(2) 工程計画図がバーチャート形式で表現される

(3) データが作業と順序関係に分かれるため, 変更が 容易である

(4) タイムラグ指定により，並行作業のずれやコンク リートの養生期間などの表現が容易である

(5) BF 関係により，ある作業に付随する準備作業の 指定が容易である

（6)工事資源の転用関係を別個に入力・表示できる （2）概略・詳細レベルの 2 階層ネットワーク構造 建設生産構造には月間・週間・日常レベルなどの階層 性があり，時間の経過とともに詳細化されることが知ら

\section{表一2 適用例の日程計算結果}

\begin{tabular}{|c|c|c|c|c|c|c|c|}
\hline No. & 作業名称 & 日数 & ES & $E F$ & LS & LF & TF \\
\hline$A 001$ & 萑備I & 4 & 0 & 4 & 0 & 4 & 0 \\
\hline B001 & 型枠粗立 & 4 & 4 & 8 & 4 & 8 & 0 \\
\hline $\mathrm{BOO2}$ & Concrete配管 & 2 & 9 & 11 & $\hat{\imath}$ & 13 & 2 \\
\hline $\mathrm{B} 003$ & 鉄筋加I & 2 & 3 & 5 & 4 & 6 & 1 \\
\hline B004 & 鉄筋組立 & 5 & 6 & 11 & $\hat{\sigma}$ & 11 & 0 \\
\hline B005 & Concrete打設 & 1 & 11 & 12 & 13 & 14 & 2 \\
\hline BO06 & 型枠解体 & 3 & 14 & 17 & 16 & 19 & 2 \\
\hline $\mathrm{COO} 1$ & 型枠粗立 & 4 & 8 & 12 & 9 & 13 & 1 \\
\hline $\mathrm{COO2}$ & Concrete配管 & 2 & 14 & 16 & 14 & 16 & 0 \\
\hline $\mathrm{C003}$ & 鉄筋加工 & 2 & 8 & 10 & q & 11 & 1 \\
\hline $\mathrm{COOH}$ & 鉄筋組立 & 5 & 11 & 16 & 11 & 16 & 0 \\
\hline Coos & Concrete打陪 & 1 & 16 & 17 & 16 & 17 & 0 \\
\hline 1006 & 型枠解体 & 3 & 19 & 22 & 19 & 22 & 0 \\
\hline
\end{tabular}

(注) $\mathrm{ES}$ : 最早開始時刻, $\mathrm{EF}$ : 最早終了時刻, LS : 最迤開始時刻 $\mathrm{LF}:$ 最還終了時刻, TF : トータルフロート

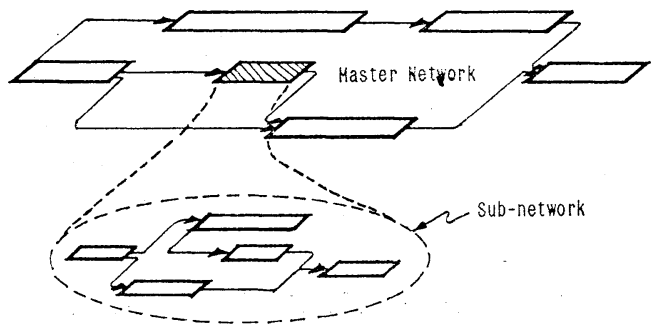

図一3２階層のネットワーク構造

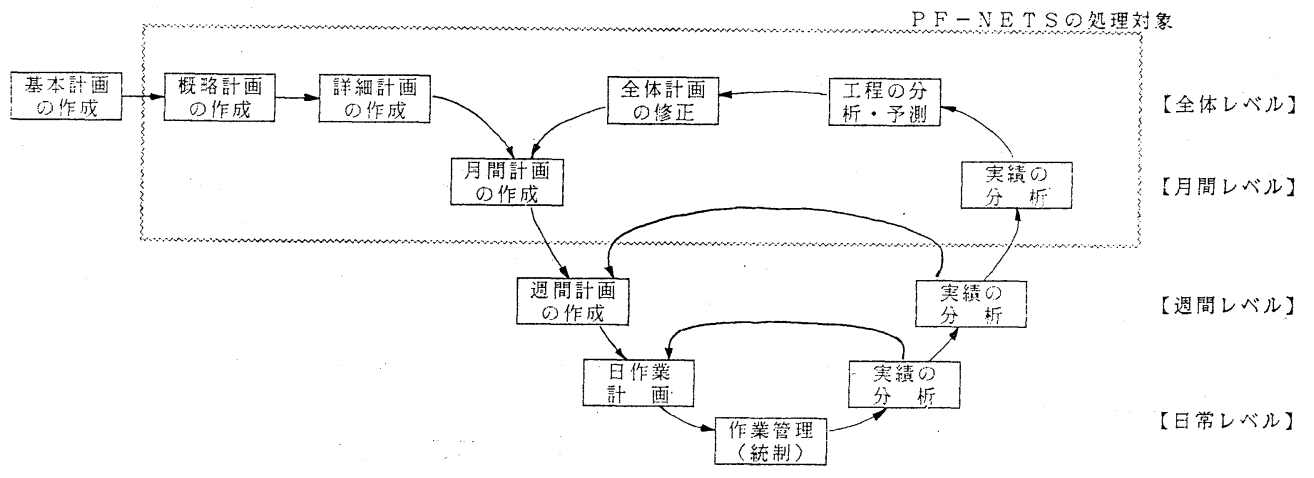




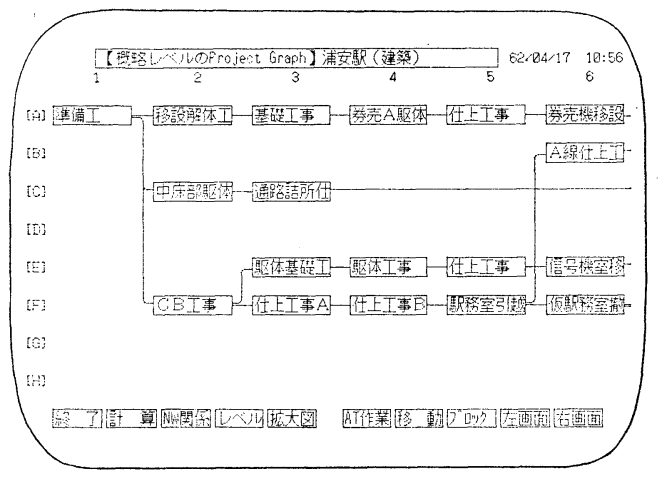

(a) 概略レベル [マスター・ホット]

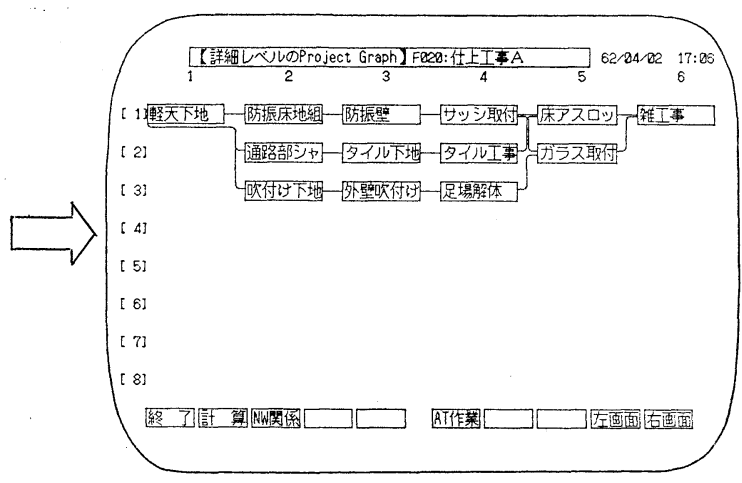

（b）詳細レベル［仕上工事Aサブ・ホット]

図一4 プロジェクト・グラフによるデータ編集

れている6). このプロセスを図化したものが 図一2 であ る. 今回のシステム開発においては，この図中の破線部 分を対象としたため, 図一3 のような概略と詳細の $2 つ$ のレベルで階層的に表現できる階層型ネットワーク・モ デルを開発した.

このモデルでは, 後述するプロジェクト・グラフで表 わした図一4のように，概略レベルと詳細レベルのネッ トワークが別々に画面に表示されるために，ネットワー クの把握が非常に容易となる.つまり，概略レベルのデ 一タ大力においては, サブネットをほとんど意識する必 要がないこと．また，詳細レベル（サブネット）のデー タ入力においても，上位のマスターネットをほとんど意 識する必要がないため, データの入力・変更作業が非常 に容易となる．さらに，工程図や月報等の管理資料をレ ベルごとに分けて出力できるため, 判断がしやすくなる といら特徵がある. なお, このモデルの日程計算は, 詳 細レベルに概略レベルの順序データを自動変換してから 行う方式をとっているため, 異なるサブ・ネットワーク の作業間においても，資源の転用関係等を表現すること が可能である.

\section{（3） プロジェクト・グラフによるデータ入カ}

周知のように，建設工事管理にネットワーク手法を適 用する場合, 計画変更に封応しやすいかどうかがキーポ イントとなる. そこで, 本システムでは, この点を改善 するためにプロジェクト・グラフを用いたデータ編集法 を開発した. このプロジェクト・グラフとは, 作業の順 序関係データをもとに, 作業の先頭からの位置 (レベル) を算出し，これによりデータをネットワーク図化したも のである7 ． 前述したように，このプロジェクト・グラ フでは, ネットワークが 2 階層の図として画面に表示さ れ, この上で作業順序関係や作業内容を編集（追加・変 更・削除) することができる ${ }^{8)}$.

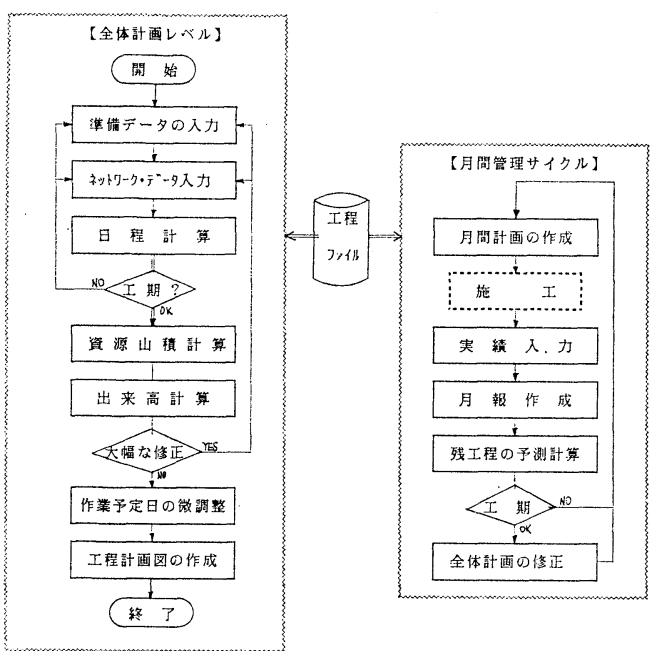

図一5 システムの処理フロー図

\section{4. 工程管理支援システム PF-NETS の開発9)}

これまでの検討から, 工程管理支援システムにネット ワーク・モデルを適用するための，いくつかの改良方法 を考案することができた，たしかに，これだけですべて の問題を解決できるわけではないが, ここまでの方法で どの程度の有効性が発揮できるのかを検証し, 新たな改 良方法を模索することも重要であると考え, パソコンを 用いた実験システムを開発した. ここで，その概要を紹 介する.

\section{（1） システムの目的と適用手法}

PF-NETS は，図一2 の波線で示したように，概略 計画以降の全体計画と，月間計画の管理業務を支援する （工程計算・管理資料の作成等）ことを目的としている. また，本システムでは，前節で説明した階層性をむった 改良 PN 法を適用している.

\section{(2) システムの機能}

本システムの機能は，図一5 に示すように工事着工ま 
での全体計画の立案と, それ以後の月間工事管理に大き く2つに分けられる.

a) 全体工程計画の立案

(1) 工事概要, 資源単価, 標準作業, ブロック名称, 休日等の登録機能

(2) ネットワーク（作業内容・順序関係）の編集機能

(3) 改良 PN 法による日程計算機能

(4) 資源別山積 (数量・金額) の計算・表示機能

(5) 工種別々累計出来䯩の計算・表示機能 (図一6)

(6) マニュアルによる日程調整機能

(7) 工程図の表示・作図機能 (図一11)

b）月間の工事管理

(1) 月間工程計画の作成（予定作業の抽出）機能

(2) 作業実績の記録・報告書作成機能

(3) 残工程の予測計算機能

(4) 残工程計画の修正機能

\section{(3) システムの特徵}

本システムは, 図一7に示した作業所設置のパソコン ですべての処理ができる，また，前述したように，階層 性をもった改良 PN 法を適用したこと，グラフによる 工程データ編集機能を有していることなどが，基本的な 特徴である.ここでは，これ以外の特徴を説明する.

a）標準作業による入力・変更作業の軽減

$\mathrm{RC}$ 構造物工事における鉄筋組等のように, 工程計画 の中で頻繁に現われる作業をこのシステムでは標準作業 とよんで, 工事種類別標準作業ファイルを作成し, 入力

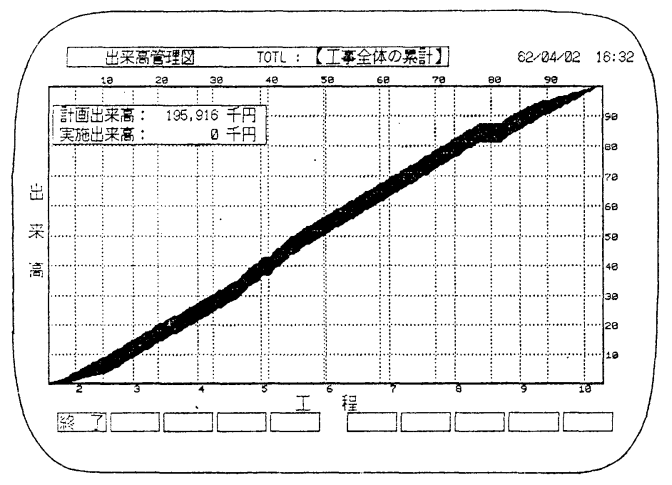

図一6 出来高金額の表示画面

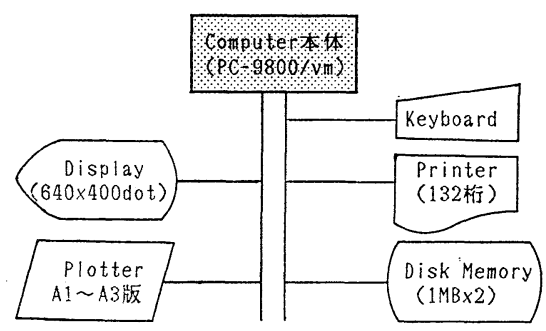

図一7 システムの機器構成
作業の軽減を図っている.

b）作業日数の設定法

これまでのシステムでは, 作業 (activity) の所要日数 は, 技術者がさまざまな条件から勘案し, 入力する方法 が取られてきた. しかし，本システムでは，所要日数を 以下に示す 3 つの方法から選択できるようにした.

(1) 確定日による指定

(2) 日当たり投入資源量による指定

(3) 作業スピードによる指定

ここで(2は，該当作業に 1 日に投入する機械や作業員 の数量 (たとえば, パーティー人数) を指定し, これと 作業数量, 歩掛りから, 所要日数を算出する方法であ る. また(3は，日当たり計画作業量（作業スピード）を 指定し, これと作業数量から所要日数を算出する方法 で，主に概略計画や資源調達能力に余裕のある工事の詳 細計画に用いられる.

以上のような機能を付加したことにより, 対話型でデ 一タを入力する際に, 歩脚り等の条件を変化させながら 検討して, 適切な所要日数を設定できるようになった. さらに, 所要日数決定の根拠を明確に記録し, 他の技術 者にも伝えることができるというメリットが生まれた.

c） 工程のシミュレート

歩掛りや作業スピードなどの所要日数設定条件を変更 することにより，作業 (activity) の所要日数を一括変更 し，簡単に工程をシミュレートすることができる．この 機能は, 計画時における検討や, 着工後に歩脚り等の実 績值を計画にフィードバックする場合に有効である.

\section{(4) システムの機器構成}

情報システム機器は 図一7 のように, 16 ビット・パ ソコン (NEC PC-9800/VM) の標準的な セットにプロ ッターを追加した構成となっている. また, 使用言語は MS-DOS のもとで動くコンパイラー型 N 88-日本語 BASIC (86) を用いた.

\section{5. 下水管敷設工事における適用例}

本システムは, 地下滞水池築造工事において最初の運 用実験を行( ${ }^{97,10)}$ ，以来システムの改良を重ね，これま でに高架橋駅部改良工事と下水管敷設工事で運用実験を 行った.ここでは特に“階層間のずれ”という現象がみ つかった下水管敷設工事の例を紹介する ${ }^{11}$.

\section{（1）工事の概要と特徵}

本工事は, 民間発注の大規模土地造成工事に伴ら下水 道工事で, 延長 $5.6 \mathrm{~km}$ にわたって下水道用ヒューム管 を道路下に開削工法で敷設する（一部推進工事を含む） ものである. 工期と規模の関係から協力業者 3 社 ( 1 社 は推進専業者)，3 工区に分割発注した. 施工環境は, ほとんどの区間が田圃と丘の間の交通量の少ない幅員 


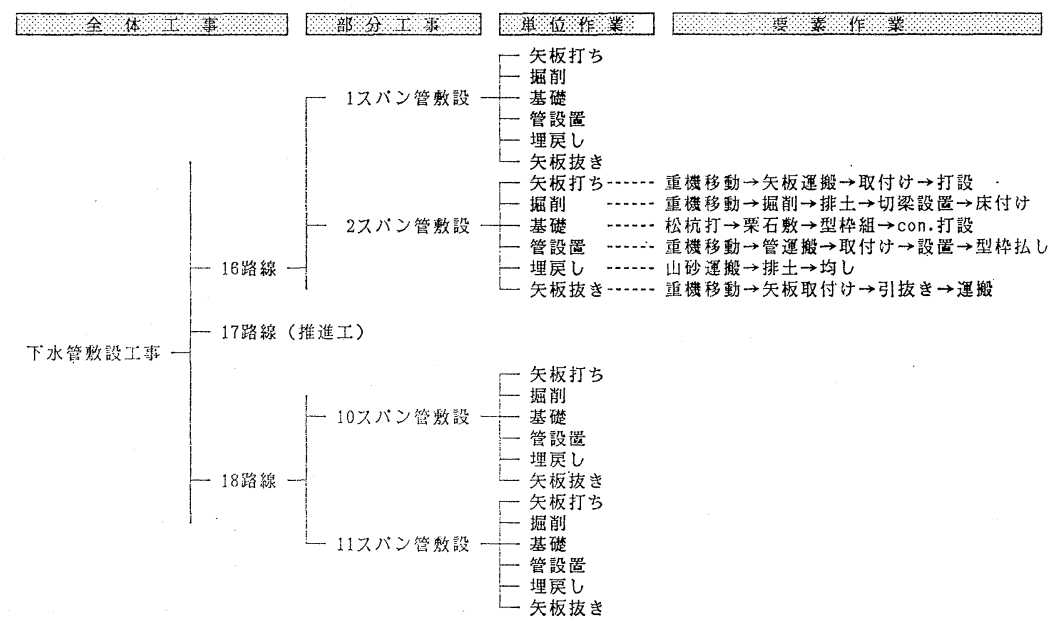

図一8 管敖設工事の WBS (一部)

$4 \mathrm{~m}$ ほどの市道で，埋設管はそれほど多くはない状況 であった。また，幅員が狭いために一部で仮設道路が必 要となり, そのための農地転用許可時期が，工程からみ た 1 つの大きな不確定要因であった. 本工事の WBS (Work Breakdown Structure) の一部を図一8 に示 す.

\section{（2）システムの適用経過}

一般に管敷設工事では，人孔と人孔の間を1スパンと よび，工事の区切りとしている．本工事においても，工 種ごとのバランスを考慮して， $30 \mathrm{~m}$ を基準として一部 の短いスパンは集約し，長いスパンは分割したが，基本 的には 1 スパンを管理の単位とした. 1 スパンの基本作 業パターンを図示すると図一9のようになる。

a) 全体概略計画への適用

全体計画では，1 スパンを 1 作業とし，日当たり敷設 延長(作業スピード) を $3.5 \mathrm{~m} \sim 5.0 \mathrm{~m}$ に変化させて, 工程のシミュレートを行った。 なお，このネットワーク は, 作業数約 200 , 順序関係数 200 程度で, 日程計算に は 1 分ほどを要した.

b) 詳細計画への適用

詳細計画では, 図一8 の単位作業を 1 作業としてネッ トワーク・データを作成した. このとき，図一10のよ うな概略と詳細のレベル分けを行った. 所要日数の算定 方法としては，矢板の打ち抜きと掘削，埋戻し作業では 日当たり資源投入数量（バイブロハンマ1台/日）を用 い，基礎構築と管設置作業では作業スピードを指定し た. このネットワークは，作業数約 400 個，順序関係数 350 個程度で, 日程計算に約 5 分ほどかかった.

\section{（3） システム適用に関する考察}

a) 処理スピード

本システムは, 従来からの大型コンピュータではな く, 16 ビット・パソコン上で稼働するため, 処理速度

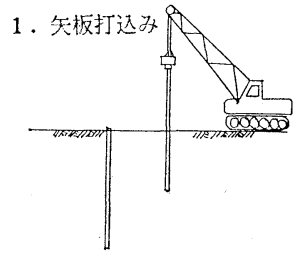

4. 管設哭

2 . 掘削

5. 埋实し

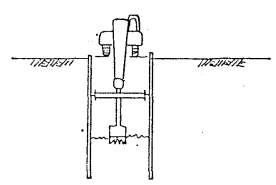

3. 基礎樥筑
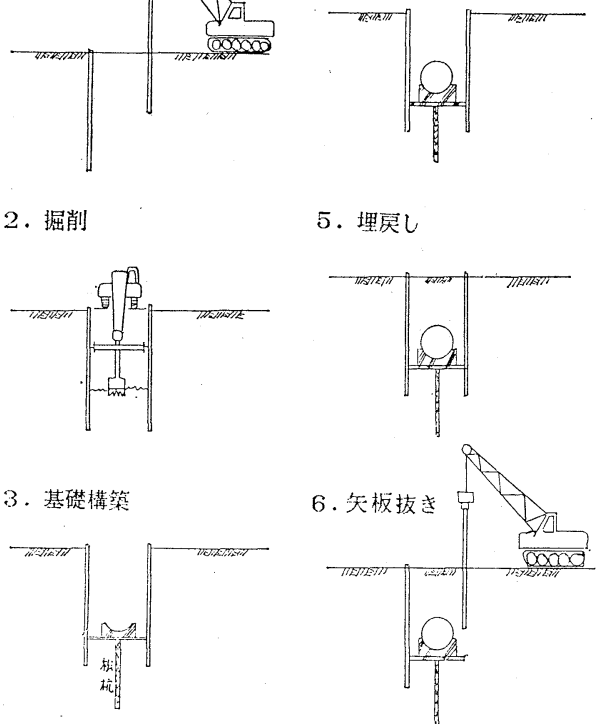

図一9 管敷設作業の基本パターン

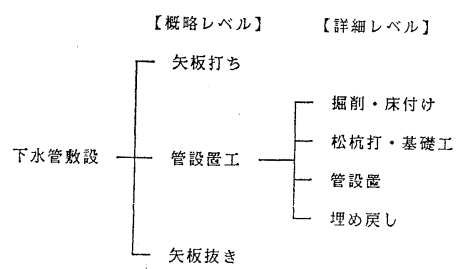

図一10詳細計画での階層化

と記憶容量が問題となるのではないかと懸念された.し かし，今回の運用実験においては，作業数が少なかった こともあり，この点は，ほとんど 問題とはならなかっ た.

b）作業所設置パソコンでの利用 
今回の運用実験では，作業所に設置したパソコンです べての処理を行った. これは, 従来のように本社設置の 大型コンピュータを利用した場合と比較して, 大幅なト ータル時間の省力化となった. また，これまで人手で行 われてきた場合には, 当初計画は PERT 的な考え方で 詳細に作成するが, 着工後は, 工程図を描き直すだけで も手間がかかるので, 大きな計画変更が生じない限り, 全体計画の修正は行わずに, 月間計画で対応するのが一 般的であった. しかし，今回のようにパソコンを利用し た場合は, その手軽さから, 月ごとに残工程を検討し, 常に最新の工程計画図を得ることができた.このこと は, 工事を管理 (manage) していくらえで大きなメリッ トであると実感した.

\section{c）データの変更}

今回適用した工事は, 工程面からみて比較的単純な工 事であったが，それでも道路下埋設物や仮設道路の民間 借地の問題, 許認可の裁可時期など, いくつかの不確定 要因があり, 施工順序がたびたび変更される状況であっ た.このような状況において, 従来のシステムを用いた 場合には, データ修正に多大な労力を必要とするのが一 般的であった. しかし, 今回の例では, 作業所設置のパ ソコン利用という点に加えて, プロジェクト・グラフに よるデータ編集機能という, より人間の視覚で理解しや すい形でのマンマシン・インターフェイスを用いたため
に，これらをスムーズに処理することができた.

d） ネットワーク・モデルの適用

改良 PN 法で工程を表現することに問題があるかど らかを判断することが，この運用実験の 1 つの大きな目 的であったが, 順序関係記述といら点では, 特に大きな 問題はなかった. ただし, 図一8 の WBS における部分 工事 (スパン単位) を概略レベルに, また単位作業 (矢 板打ち等）を詳細レベルに対応させて，本システムの 2 階層ネットワーク・モデルを適用しようと当初検討した が，これをうまく表現することはできなかった.

これは, 図一12 のように後続スパンの矢板打作業が， 先行スパンの矢板抜作業に先行するというょうに; 詳細 レベルにおける作業間の関係と, 概略レベルにおけるも のとが完全には一致しないことに起因している. このた め, 前述したように, 今回の運用実験では, スパン単位 で表現した概略工程計画と, 矢板の打ち抜き作業を単位 とした詳細工程計画の 2 種類を, 別個に作成しなければ ならなかった. 以上のことは, 管敷設工事では単純な階 層モデルが適用できないことを示している. そこで，こ のような現象のことを，特に “階層間のずれ”とよぶこ ととする.このような現象は, 管敷設工事に特有のもの かどうか, 今後の研究結果を待たなければならないが, 経験的な判断からすると，他のタイプの工事でもみられ る現象ではないかと推定できる.

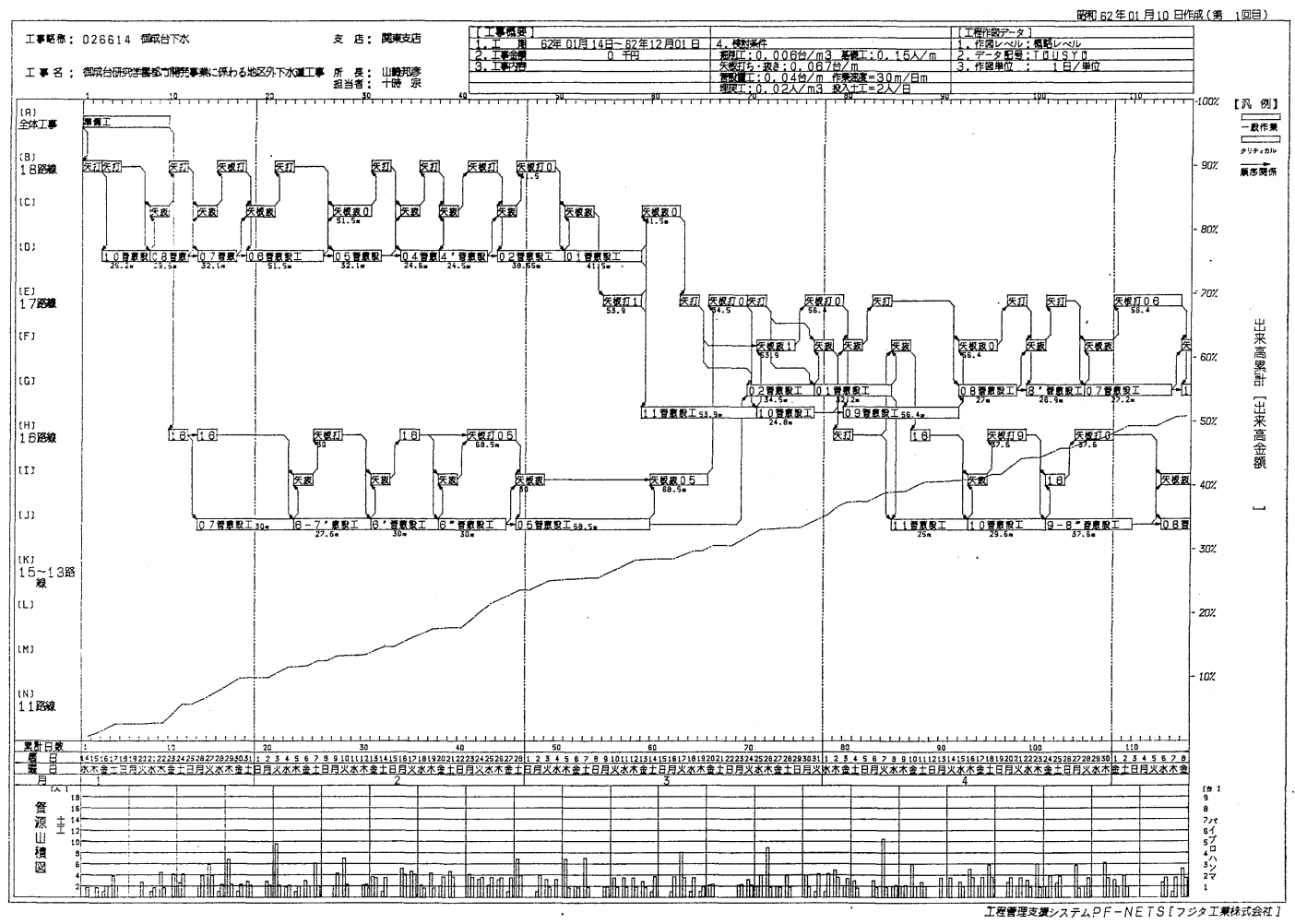

図一11 下水道管敷設工事の工程計画図 (一部) 


\section{6. 概念ネットワークと知識工学適用の考え方}

\section{(1) 概念ネットワーク}

前節において，管敷設工事では工程ネットワークを階 層的に表わす場合，階層間のずれという問題点があるこ とがわかった。 このようなネットワークは, 従来からの 階層型モデルで表現することは困難で，あえて表現しよ うとすると，概略レベル作業間の関係を SS 関係により 並行作業として表現しなければならなくなる.しかし， こうしてできた概略レベルのネットワークは，概念的な 順序関係を簡潔に表わすものではなくなってしまうた め, これを使って工程を把握することは困難である.

また，視点を変えて，工程計画にネットワーク手法を 適用する場合に重要となる, データ作成労力の低減化に ついて考えてみると，このための手段として，これまで データ・ベースの利用が検討されてきた. しかし，この 方法は作業を詳細レベルに分解するためには有効な手段 であるが，ここでわかったように，建設生産活動が単純 な階層構造で表わせないとすると，これらの作業の順序 関係は，やはり技術者が詳細レベルまで注意を払って， 設定しなければならないことになる.このことは, 計画 時の代替案の検討や, 工事着手後に頻繁に起こるネット ワークの組替えにおいて，大きな労力を技術者に強いる 結果となる．以上のことから，(1)建設工事のネットワー クを厳密に階層構造で表わすことが困難であること，こ のために(2)データベースを利用した場合でも，順序関係 の設定には多大な労力が必要であることが理解できる.

以上の問題の対応策の 1 つとして, 概略レベル作業の 投入資源量を時系列的に指定できるようにし，このレベ ルのネットワークで管理する方法が考えられる。しか し，このようなモデルでは(1)階層間のずれから起こる概 略レベル作業間の重複が表現しにくい（SS 関係での表 現は可能である) こと, (2)システムを週閒や日常レベル に拡張しにくいこと, などの問題がある. そこで, これ らの問題を解決する方法として, 図一12 で示した階層 間のずれをその構造に取り込み，概略レベルのネットワ 一クを入力すると, 工程計算のもととなる詳細レベルの ネットワークを自動的に生成するようなモデルの開発が 必要と考える. この場合, 従来のものとは異なり, この モデルの概略レベル・ネットワークでは, 作業の 順序関係は技術者の設定（概念）どおり表現する が，作業の開始・終了時刻は厳密には表現しない ことになる（ただし，詳細作業の開始・終了時刻 は峳密に計算される).このため, 以後, このよ うなネットワークを概念ネットワーク (concep tional network) とよぶこととした.

\section{(2) 知識工学適用の考え方}

この概念ネットワークでは，工事の概略レベルの順序 関係は技術者が指定し，これらの概略作業を詳細作業へ 自動的に分解し, さらに, 詳細作業の順序関倸を自動発 生させ，これを使って日程計算を行うという考え方が基 本となっている.このような考えを処理フローで表わし たものが 図一13 である.このような考えは，当然のこ とながら, 現在研究が進められている知識工学の適用が 前提となっている. この図において, Step. 2 「概略作業 を詳細作業へ分解」では，データ・ベースと知識工学を 合わせた方法が有効と考える．また，Step. 3 「詳細レベ ル順序関係の生成」では, やはり従来からの経験的知識 を利用した知識工学の適用が有効と考える.ここでは, 図一12 の下水管敷設問題を例として, 順序関係の生成 における知識工学適用の考え方について述べる.

図一12 の詳細レベルの順序関係を詳しく検討すると， 以下のように 3 種類に分類できる.

[関係 (1)] 1 スパン内の関係（矢板打工 $\rightarrow$ 管設置工 $\rightarrow$ 矢板拔工)

[関係 (2)] 管設置工間の関係 (10スパン $\rightarrow 9$ スパン $\rightarrow$

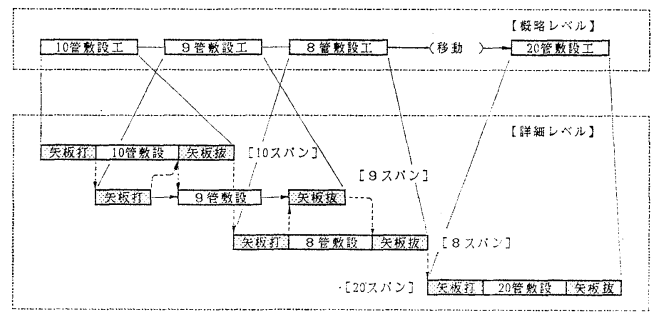

図一12 階層間におけるネットワークのずれ

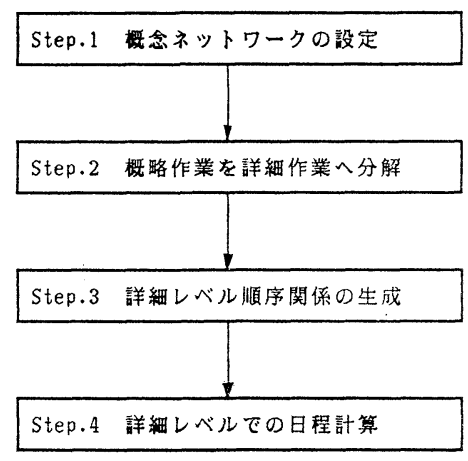

図一13概念ネットワークにおける処理フロー

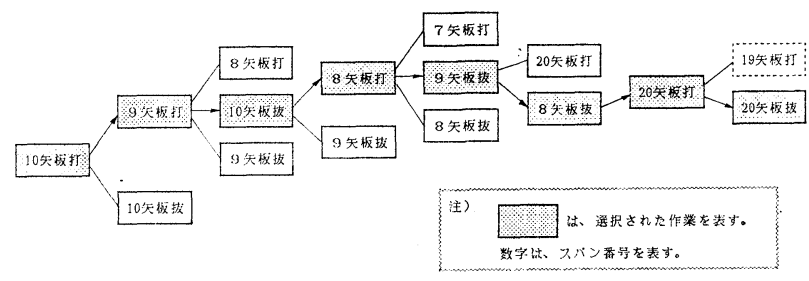

図一14 矢板打 · 矢板抜作業の順序選定過程 


$$
8 \text { スパン) }
$$

[関係 (3)] 矢板打ち抜きの関係

この中で，[関係 (1)］は技術的な制約条件から，すべ てのスパンにおいて決定される. また，[関係 (2)] は概 念ネットワークにより設定される. しかし，実施工にお いてバイブロハンマの移動で表わされる [関係 (3) より複雑な条件を考慮しないと設定することができな い. この順序決定問題は, 技術的に可能な作業順序の中 から，他の制約条件 (経験的知識) によって最適と考え られる経路をヒューリスティック (heuristic) に選定す る組合せ問題として表現することができる.これらの経 験的知識 (ルール) は, 順序関係の決定のものだけに限

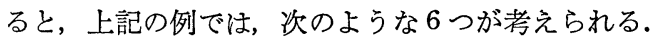

[関係 (1)]より,

(1) 同スパンの矢板打と矢板抜作業が逆にならない [関係 (2)]より,

(2) 先行スパンより前に後続スパンの矢板打は開始で きない

(3) 先行スパンより前に後続スパンの矢板抜が終了で きない

バイブロハンマーの移動量を最小化するために,

(4) 施工スパンが飛ぶ場合は，矢板抜を終えてから移 動する

これまでのルールで, 選択可能な組合せ案が複数存在 する場合は,

(5) 遊休矢板がある場合は，矢板打作業を優先する

(6) そうでない場合は，矢板抜き作業を行う

以上のルールを用いて, 矢板打・矢板抜作業の順序選 定過程を表わしたものが 図一14 である. 一般的に, こ のような 経路選定問題に㧤いては, “組合せ的爆発”を いかに防ぐのかが重要な問題となるが，概念ネットワー クによる方法では, 技術者があらかじめ基本的な順序関 係を設定しているため, このような問題は起こらず，上 記のルールをプロダクション・ルールとして表現し, 仮 設を立てて推論を行う仮設推論により決定することが可 能だと考えられる.

\section{7. おわり}

これまで述べてきたように，PF-NETS の 運用実験 の結果から, 今回のように作業所で直接操作ができる工 程管理支援システムは有効であるとの自信を深めること ができた. そして論文の最後に，残された問題点を解決 する方法として，概念ネットワークと知識工学手法適用 の考え方を示した. この結果, 概略作業を詳細作業に分
解するための知識だけでなく, 建設工事を生産パターン で分類し, 各パターンにおける詳細作業の順序関係設定 ルールを, 経験的知識として整理・蓄積する必要がある ことがわかった. また，これらの知識を効率的にシステ ム化するための知識工学手法についてはシステム実用化 のための重要な課題と考え, 今後さらに研究を進める所 存である。

なお，本研究は，執筆者の一人である池田が昭和 59 年 4 月より 2 年間におたり，フジタ工業（株）より京都 大学に研究員として派遣された際の研究活動をベースと して発展させてきたものである. 最後に, 研究室在籍以 来, 始終, 協力・助言を賜った京都大学工学部土木工学 科土木計画学研究室のメンバー各位, ならびに吉井良二 部長を始めとするフジタ工業（株）土木本部工事統括部 の方々，および運用実験に協力していただいた関東支店 御成台下水作業所の方々に深く感謝する次第である.

\section{参 考 文 献}

1）春名 攻・藤田興一・池田將明 : 地下滞水池築造工事に おける現場管理トータルシステムの開発について, 土木 学会第 41 回年次学術講演会, 1986 年 11 月.

2) 山本幸司 : 施工計画・管理手法としてのPERT 系技法の 現状と今後, 土木工事のマネジメント問題に関する研究 討論会講演資料集, 1983 年 11 月.

3）池田將明・吉川和広・春名 攻: 資源制約を 考慮した工 程計画システム化の研究, 土木学会第 40 回年次学術講演 会, 1985 年 9 月.

4) 嘉納成男 : 概略工程計画手法の開発一建築工事の工程計 画に関する研究 (その 1), 日本建築学会計画系論文報告 集, 第 359 号, 1986 年 1 月.

5）吉川和広・春名 攻・池田將明 : パソコンを用いた現場 マネジメントシステムの実験的開発について, 土木計画 学研究・講演集 No. 7, 1985 年 1 月.

6）田坂隆一郎 : 土木施工の工事計画・管理のシステム化に 関する実証的研究, 京都大学学位論文, 1983 年 6 月.

7) 吉川和広 : 土木計画と OR, 丸善.

8）春名 攻・池田將明 : On-site Management System の開 発方法に関する研究, 土木計画学研究・講演集 No. 8 , 1985 年 10 月.

9）吉川和広・春名 攻・池田將明 : オンサイトマネジメン トに掞りる工程計画システムの利用に関する研究, 第 10 回電算機利用シンポジウム, 1985 年 10 月.

10) Ikeda, M., Yoshikawa, K. and Haruna, M. : Development of Personal Computer-based Management System for On-site Construction Planning and Scheduling, International Conference on THE USE OF COMPU. TERS IN CIVIL ENGINEERING, August 15 16, 1985, TORONTO, CANADA.

11）吉井良二・池田將明：工程管理支援 システム（PF-NET S) の開発と適用に関する研究, 第 5 回建設マネジメント 問題に関する研究発表・討論会, 1987 年 12 月.

(1987.11.13, 受付) 